DOl:10.18276/epu.2015.121-18

\title{
Magdalena Wiśniewska*
}

\author{
KONCEPCJA LIVING LAB \\ WE WDRAŻANIU NOWYCH ROZWIĄZAŃ W ORGANIZACJACH - \\ PRZYKLAD SCOUTINGU WIEDZY \\ W UNIWERSYTECIE LÓDZKIM
}

\begin{abstract}
Streszczenie
Koncepcja Living Lab jest stosunkowo nowym podejściem do tworzenia i wdrażania nowatorskich rozwiązań w organizacjach. Jej podstawowym założeniem jest uczestnictwo użytkowników końcowych w całym procesie tworzenia nowości. U podstaw tejże koncepcji leży przeświadczenie, iż efektywność nowych rozwiązań będzie wyższa, gdy ci końcowi użytkownicy będą kreować nowość w warunkach jej rzeczywistego stosowania. Artykuł przybliża koncepcję Living Lab oraz przedstawia praktyczne możliwości jej zastosowania. Rozważania teoretyczne poparte zostały studium przypadku scoutingu wiedzy - rozwiązania przygotowanego i testowanego w Uniwersytecie Łódzkim.
\end{abstract}

Słowa kluczowe: innowacje, Living Lab, scouting

\section{Wprowadzenie}

Tworzenie innowacji może się dokonywać w ujęciu podażowym, gdzie innowacje stanowią pochodną wyników badań naukowych, a konsument ma z nimi do czynienia w momencie ich sprzedaży. Takie podejście rodzi ryzyko niedostosowania nowości do potrzeb konsumenta, gdyż popyt na dane dobro jest jedynie przewidywany, szacowany. Model popytowy innowacji przyjmuje z kolei, iż to

* Magdalena Wiśniewska, dr, Uniwersytet Łódzki, Wydział Zarządzania, e-mail: magdalena.wisniewska@uni.lodz.pl 
popyt na określone dobra stanowi punkt wyjścia dla wdrażanych nowości. Daje to szanse na większe dopasowanie opracowywanych nowości do potrzeb odbiorców. Podejście user-driven (ang. „napędzane” przez uży tkowników) w tworzeniu innowacji zakłada włączenie ostatecznych użytkowników w proces innowacyjny. To właśnie użytkownicy danego produktu czy usługi są bowiem najlepszym źródłem wiedzy o potrzebach w zakresie jego charakterystyki. W tym podejściu jednak ostateczna weryfikacja zastosowania danego dobra w warunkach rzeczywistych wciąż następuje dopiero po jego wdrożeniu na rynek. Rodzi to określone ryzyka, w tym niespełnienie w pełni oczekiwań odbiorców. Szansę na opracowanie rozwiązania całkowicie uwzględniającego potrzeby odbiorców, zwłaszcza w kontekście potrzeb nowych lub niejasno sprecyzowanych, daje zastosowanie koncepcji Living Lab.

Living Lab jest dość nowym podejściem do tworzenia nowatorskich rozwiązań. Źródła pomysłu należy upatrywać w Massachusets Institute of Technology i osobie Williama Mitchella, inspiratora nowatorskich podejść urbanistycznych ${ }^{1}$. Obecnie koncepcję tę odnosi się do kreowania każdego rodzaju nowatorskich rozwiązań, jednakże przy założeniu, by były one opracowane w warunkach ich rzeczywistych zastosowań przy naczelnym zaangażowaniu użytkowników. Włączani są oni w proces rozwoju danej idei, tworzenia prototypu, jego testowania czy walidacji ${ }^{2}$.

Living Lab jest tym samym koncepcją angażującą do rozwijania pomysłów i tworzenia innowacji użytkowników w poszczególnych fazach procesu, a więc odkrywania nowości, ich prototypowania, walidacji i usprawniania ${ }^{3}$. Wdrożenie koncepcji Living Lab zakłada, iż innowacja powstaje przy zaangażowaniu użytkowników, we współpracy z sektorem gospodarki oraz przy użyciu dostępnych technologii (rysunek 1).

1 D. Stawasz, M. Wiśniewska, Wykorzystanie koncepcji Living Lab w zarządzaniu jednostkami samorząu terytorialnego, Wydawnictwo Katedry Zarządzania Miastem i Regionem, Wydział Zarządzania Uniwersytetu Łódzkiego, Łódź 2015, s. 20.

2 Walidacja to uzyskanie ostatecznego dowodu na to, iż opracowane rozwiązanie jest skuteczne w założonej funkcji, spełnia założone wymogi, standardy.

3 N. Lama, A. Oigin, Innovation ECOSYSTEMS: Services Engineering \& Living Labs a Dream to Drive Innovation?, Presentation at the EU/IST conference, Helsinki 2006. 


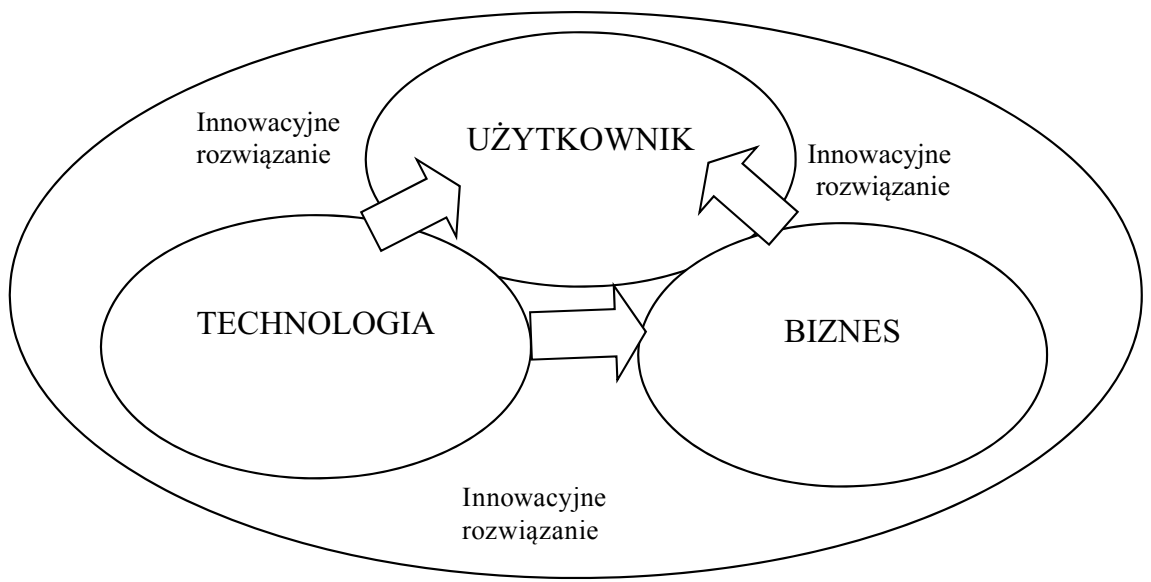

Rysunek 1. Partnerstwo w ramach Living Lab

Źródło: opracowanie własne na podstawie: V. Niitamo, S. Kulkki, M. Eriksson, K.A. Hribernik, State-of-the-Art and Good Practice in the field of Living Labs, www.researchgate.net/ profile/Karl_Hribernik/publication/228367848_State-of-the-art_and_good_practice_ in_the_field_of_living_labs/links/5491652d0cf222ada8588a92.pdf (dostęp 19.09.2015).

\section{Istota koncepcji Living Lab}

Istnieją różne spojrzenia na istotę koncepcji Livin Lab ${ }^{4}$ I tak Living Lab definiowane bywa jako:

- środowisko (ang. environment) ${ }^{5}$,

- metodologia ${ }^{6}$,

- system $^{7}$.

${ }^{4}$ B. Bergvall-Kareborn, A. Stahlbrost, Living Lab-An Open and Citizen-Centric Approach for Innovation, „International Journal of Innovation and Regional Development” 2009, s. 365-370.

5 P. Ballon, J. Pierson, S. Delaere, Test and Experimentation Platforms for Broadband Innovation: Examining European Practice, w: Conference Proceedings of 16th European Regional Conference by the International Telecommunications Society (ITS), Porto, Portugal, 4-6 September, 2005; H. Schaffers, M.C. Cordoba, P. Hongisto, T. Kallai, C. Merz, J. van Rensburg, et. al., Exploring Busniess Models for Open Innovation in Rural Living Labs, w: Proceedings of the 13th International Conference on Concurrent Enterprising, Sophia-Antipolis 2007, s. 49-56.

6 M. Eriksson, K.A. Hribernik,. State-of-the-art and Good Practice in the Field of Living Labs, w: Proceedings of the12th International Conference on Concurrent Enterprising: Innovative Products and Services through Collaborative Networks, Milan 2006, https://pure.ltu.se/portal/ files/3517934/19706123_Paper.pdf (dostęp 20.09.2015).

7 CoreLabs., Living Labs Roadmap 2007-2010, Recommendations on Networked Systems for Open User-Driven Research, Development and Innovation, http://pl.scribd.com/doc/38953413/ Living-Labs-Roadmap-2007-2010\#scribd (dostęp 1.07.2015). 
Powyżej wskazane ujęcia nie stoją w sprzeczności ze sobą, a stanowią wzajemnie uzupełniające się perspektywy. Ich zrozumienie pozwala na lepsze rozpoznanie specyfiki koncepcji i daje szansę na bardziej efektywne jej stosowanie.

$\mathrm{Z}$ uwagi na fakt, iż koncepcja Living Lab jest bardzo nowatorska, wykształcenie sprawnie działających procesów, powiązań, relacji odbywa się na podstawie doświadczeń zdobytych $\mathrm{w}$ drodze dotychczasowych inicjatyw. Podmioty wykorzystujące koncepcję Living Lab powołały w 2006 roku Europejską Sieć Living Labs (European Network of Living Labs ENoLL) na rzecz dzielenia się wiedzą, doświadczeniami i dobrymi praktykami.

Patrząc na koncepcję z perspektywy środowiskowej, trzeba uznać, iż wykreowanie właściwego otoczenia, atmosfery współpracy, integracji środowiska wraz z towarzyszącymi obiektami, wyposażeniem jest pierwszoplanowe. Można wskazać następujące kluczowe komponenty środowiska Living Lab:

1. Użytkownik. Użytkownicy stanowią naczelny element podejścia Living Lab. Końcowych użytkowników opracowywanego rozwiązania rozumiemy jednocześnie jako jego pomysłodawców, współautorów, testujących i walidujących. Inaczej mówiąc, stworzenie środowiska Living Lab wymaga aktywnego zaangażowania użytkowników.

2. Środowiskozastosowania. Środowisko zastosowania finalnego rozwiązania powinno być tożsame ze środowiskiem jego powstawania. Oznacza to, iż proces odkrywania nowych pomysłów, ich opracowywania, testowania, prototypowania itd. nie może odbywać się w warunkach sztucznych, laboratoryjnych. Koncepcja Living Lab wymaga zapewnienia warunków rzeczywistych, co ma umożliwić stworzenie nowości, która sprawdzi się w tych warunkach, kiedy będzie już wdrożona do codziennego użytku.

3. Technologia i infrastruktura. Technologie informacyjne i komunikacyjne odgrywają istotną rolę w łatwiejszej komunikacji i kooperacji w ramach Living Lab pomiędzy partnerami i interesariuszami przedsięwzięcia. Chodzi o stworzenie optymalnych warunków do sprawnego komunikowania pomysłów, ich szybkiej oceny, konfrontacji, wymiany doświadczeń.

4. Organizacja $i$ metody. Koncepcja Living Labs jest z pewnością wyzwaniem i wymaga właściwej organizacji, warsztatu pracy, metod. Należy jednak mieć na uwadze, iż nowatorskość tego podejścia i jego założenia powodują, że nie jest możliwe skopiowanie przyjętego gdzieś rozwiązania. Z pewnością jednak można czerpać z już zrealizowanych inicjatyw. 
5. Partnerzy. Współpraca partnerów wraz z ich specyficznymi punktami widzenia, posiadaną wiedzą, umożliwia poprawę standardów opracowywanych rozwiązań, przybliżając je do rozwiązań doskonałych. Trzeba mieć na uwadze, iż poza konsumentami opracowywanego rozwiązania $\mathrm{w}$ proces jego powstawania powinno się włączyć także podmioty dysponujące wiedzą, doświadczeniami, kompetencjami czy możliwościami finansowania w odniesieniu do generowanej nowości (rysunek 2).

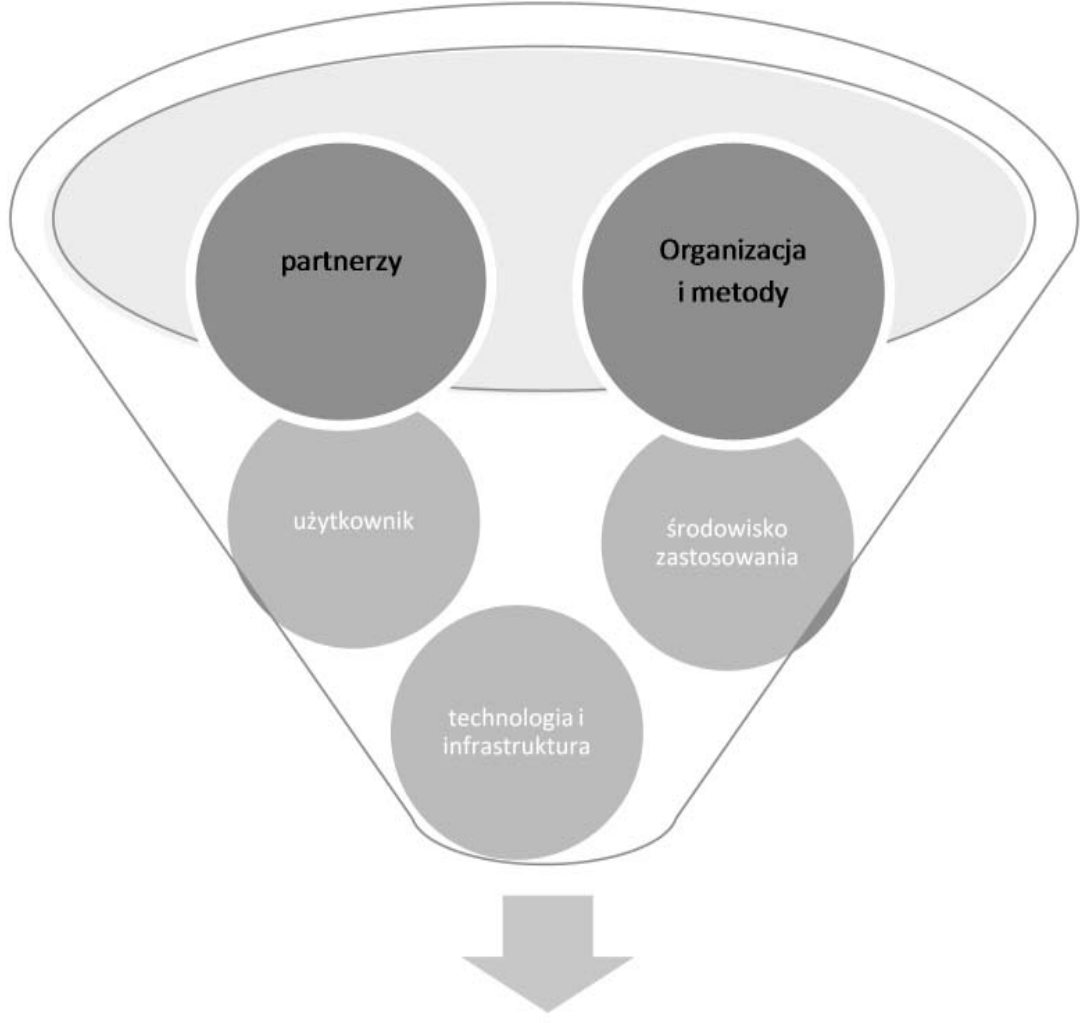

\section{innowacyjne rozwiązanie}

Rysunek 2. Kluczowe komponenty środowiska Living Lab

Źródło: opracowanie własne na podstawie: CoreLabs., op. cit. 
Perspektywa metodologiczna rozumienia koncepcji Living Lab uwypukla znaczenie procesów zachodzących podczas realizowanych projektów, jak np. procesy wymiany danych oraz metody zaangażowania użytkowników opracowywanych rozwiązań. Tutaj należy wskazać pięć naczelnych zasad wdrażania Living $\mathrm{Lab}^{9}$ :

1. Kontynuacja. Postulat ten oznacza wymóg ciągłości procesów. Szczególnie ważne jest to przy nawiązywaniu relacji współpracy pomiędzy partnerami przedsięwzięcia. $Z$ uwagi na fakt łączenia różnych grup interesu, stworzenie bliskich relacji między nimi wymaga czasu. Aby proces ten był efektywny, należy zapewnić mu ciągłość.

2. Otwartość. Wymóg ten odnosi się do wysiłku na rzecz uwzględnienia mnogości perspektyw oraz zgromadzenia odpowiedniej ilości sił dla osiągnięcia postępu prac w ramach przedsięwzięcia. Otwartość oznacza także uwzględnianie w maksymalnym stopniu użytkowników z ich potrzebami i punktami widzenia jako podstawą tworzonych innowacji.

3. Realizm. Potrzeba realizmu związana jest $\mathrm{z}$ oczekiwanym rezultatem produktem czy usługą możliwą do zastosowania w rzeczywistych warunkach jej użytkowania. Środowisko przeprowadzania Living Lab musi tym samym być jednocześnie środowiskiem późniejszego korzystania z opracowanych nowatorskich pomysłów. Ta cecha koncepcji Living Lab odróżnia ją w szczególności od innych koncepcji opracowywania, testowania czy walidacji innowacji.

4. Upodmiotowienie użytkowników. Postulat ten jest kluczowy dla prowadzenia procesu innowacji w zamierzonym kierunku, a więc bazującym na potrzebach ludzi. Efektywność koncepcji opiera się na kreatywności społeczności użytkowników, dlatego też ważne jest motywowanie i zaangażowanie użytkowników w proces innowacyjny.

5. Spontaniczność. Spontaniczność działania wiąże się z cyklem tworzenia innowacji i koniecznością rejestracji, zbierania i analizy spontanicznych reakcji użytkowników na każdym z etapów tworzenia nowości. Nie wystarczy zaangażować użytkowników w jeden z etapów procesu innowacyjnego. Punkty widzenia, reakcje, w tym zwłaszcza te spontaniczne, powinny być uwzględniane dla zapewnienia skuteczności generowanych rozwiązań (rysunek 3). 


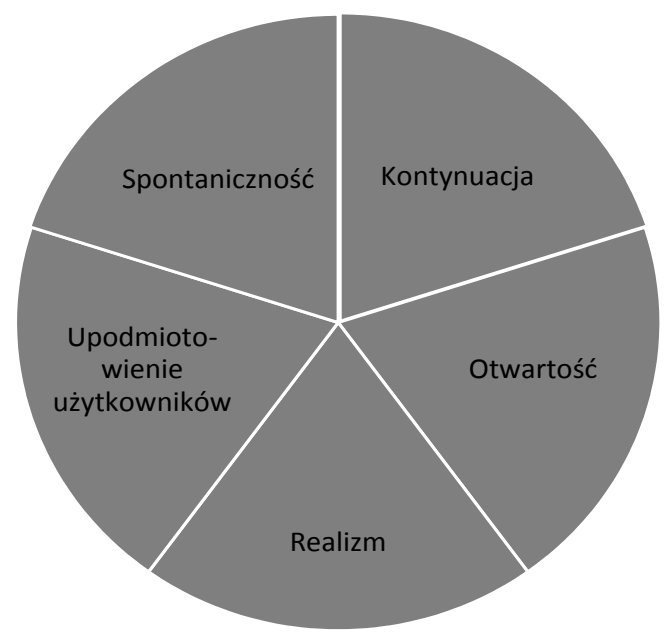

Rysunek 3. Naczelne zasady wdrażania Living Lab

Źródło: jak pod rysunkiem 2.

Perspektywa systemowa rozumienia podejścia Living Lab koncentruje się na relacjach pomiędzy jego elementami. Mechanizmy łączące taki społeczno -techniczny system są wielowymiarowe. W ramach Living Lab zachodzą interakcje między zaangażowanymi grupami interesariuszy, poszczególnymi osobami a fizycznym środowiskiem, w którym tworzą, czy testują nowe pomysły.

\section{Rola interesariuszy w koncepcji Living Lab}

Koncepcja Living Lab nie jest jedyną w obszarze kreowania, testowania i walidowania innowacji. Tym, co ją wyróżnia, jest wysoki stopień partycypacji różnych grup podmiotów oraz mnogość uwzględnianych (nie zawsze zaplanowanych) kontekstów (co wynika ze spontanicznej natury Living Lab). Należy jednak mieć na uwadze, iż zaangażowanie samych użytkowników w koncepcji Living Lab nie wyczerpuje jej założeń. Konieczne jest zaangażowanie możliwie szerokiej grupy interesariuszy ${ }^{10}$.

${ }^{10}$ Koncepcja zarządzania przy udziale interesariuszy w literaturze nazywana jest koncepcją stakeholders. Interesariusze to osoby, grupy osób, instytucje, które są zainteresowane wynikami działania danej organizacji. Zgodnie z podejściem stakeholders, „organizacja jest wtedy najbardziej efektywna, kiedy znajduje punkt równowagi interesów różnych interesariuszy wyrażający się optymalną relacją ich korzyści do ponoszonych przez nich kosztów". M. Bielski, Podstawy teorii organizacji i zarzadzania, wyd. 2 rozsz., C.H. Beck, Warszawa 2004, s. 67. 
Angielskie słowo stakeholders najczęściej tłumaczy się jako „interesariusze", a więc osoby, grupy osób, instytucje, które są zainteresowane wynikami funkcjonowania danej organizacji. Interesariusze to - inaczej mówiąc - każda osoba (lub grupa osób) wpływająca lub będąca pod wpływem jakiegoś podmiotu. Interesariusze:

- są podmiotami, których dotyczy dane zagadnienie,

- są odpowiedzialni za dane zagadnienie,

- są w posiadaniu wiedzy lub umiejętności w zakresie sprawnego radzenia sobie z danym zagadnieniem,

- są w posiadaniu narzędzi i środków ku temu, by wdrażać rozwiązanie lub je hamować.

Interesy tych podmiotów mogą być nieco odmienne, a czasami nawet sprzeczne. Postulat pogodzenia ze sobą interesów wszystkich jest często trudny lub wręcz niemożliwy do spełnienia. Tym niemniej można powiedzieć, iż realizacja interesu jednej z grup może pociągać za sobą pośrednio lub bezpośrednio realizację interesu innej grupy. Właściwe odpowiedzenie na potrzeby różnych grup interesu wymaga wsparcia procesu tworzenia nowości ze strony także władzy publicznej oraz potencjalnych dostawców nowych rozwiązań (biznesu) jak i nauki (która daje kreatywne zasoby ludzkie, laboratoria, procedury itp.).

Teoria odnosząca się do interesariuszy zawiera cztery podstawowe założenia:

1. „Organizacja funkcjonuje w otoczeniu grup interesów zawiązujących się zarówno we wnętrzu, jak i na zewnątrz organizacji. Zachowanie tych grup z jednej strony istotnie wpływa na funkcjonowanie organizacji, z drugiej zaś jest przez organizację kształtowane, co powoduje, że owe grupy interesów, określane mianem interesariuszy (stakeholders), mają na nią wpływ.

2. Teoria interesariuszy koncentruje się na naturze relacji zachodzących między organizacją a grupami interesów oraz na korzyściach będących wynikami tych relacji.

3. Organizacja działa $w$ interesie wszystkich interesariuszy posiadających umocowanie, co oznacza, że interes każdego z nich ma swoją wewnętrzną wartość, która musi być analizowana i rozważana odrębnie; nie jest zatem możliwy układ, w którym pewna koalicja interesariuszy narzuciłaby organizacji, i co za tym idzie pozostałym interesariuszom, swoją wiązkę celów i swój układ interesów. 
Teoria interesariuszy koncentruje się na podejmowaniu decyzji zarządczych i na skutkach tych decyzji”'11. Zaangażowanie możliwie najszerszej grupy interesariuszy zwiększa szansę na stworzenie rozwiązań optymalnych dzięki uwzględnieniu mnogości punktów widzenia, umożliwia też redukcję ryzyka technologicznego i biznesowego. Wyzwaniem jest pogodzenie interesów poszczególnych grup. Należy też zauważyć, iż zaangażowanie wielu osób czy instytucji musi odbywać się w taki sposób, by nie zakłócało realizacji projektu i umożliwiało spełnienie innych założeń koncepcji Living Lab, jak spontaniczność czy kontynuacja.

\section{Wdrożenie scoutingu wiedzy w Uniwersytecie Lódzkim jako przyklad zastosowania koncepcji Living Lab}

Projekt „SCOUTING - aktywny system monitoringu i oceny potencjału rynkowego prac badawczych kluczem do współpracy nauki i przedsiębiorców" był projektem innowacyjnym testującym, realizowanym w ramach Programu Operacyjnego Kapitał Ludzki. Jego wdrożenie było możliwe dzięki zawiązaniu partnerstwa pomiędzy: Wydziałem Zarządzania Uniwersytetu Łódzkiego (główny wykonawca, lider partnerstwa), Universidad de Cádiz (partner ponadnarodowy), Politecnico di Torino (partner ponadnarodowy) oraz Centrum Transferu Technologii Uniwersytetu Łódzkiego (partner wewnętrzny) ${ }^{12}$.

Jako projekt o charakterze innowacyjnym testującym, finansowany ze środków Unii Europejskiej, podlegał on pewnej z góry narzuconej strukturze i sekwencji działania. Częściowo powodowało to usztywnienie procedur decyzyjnych (każda zmiana we wniosku projektowym musiała być poprzedzona zgodą instytucji pośredniczącej, unijne procedury raportowania i publiczne procedury wydatkowania środków). Sama idea projektów innowacyjnych testujących okazała się zbieżna z koncepcją Living Lab.

Fazy projektu można przedstawić następująco (rysunek 4):

1. Faza przygotowawcza:

a) podjęcie inicjatywy o przystąpieniu do projektu innowacyjnego testującego,

b) identyfikacja problemu,

11 Sz. Cyfert, K. Krzakiewicz, Teoria stakeholders. Krytyka założeń. Stan i perspektywy rozwoju teorii i praktyki zarzadzania na progu XXI wieku, Prace Naukowe Akademii Ekonomicznej we Wrocławiu nr 940, Wrocław 2002. s. 147, za: D. Stawasz, M. Wiśniewska, op. cit.

12 M. Wiśniewska, P. Głodek, M. Żak-Skwierczyńska, Scouting - system identyfikacji i monitoringu wiedzy w uczelni wyższej, jako instrument na rzecz wzmocnienia powiąań nauki i biznesu, Folia Oeconomica z. 277, Wydawnictwo Uniwersytetu Szczecińskiego, Łódź 2012. 
c) identyfikacja interesariuszy - ostatecznych użytkowników i beneficjentów rozwiązania,

d) wstępne opracowanie pomysłu (wymóg konkursowy),

e) przystąpienie do konkursu w ramach Programu Operacyjnego Kapitał Ludzki.

2. Faza opracowania założeń:

a) powołanie zespołu zarządzającego,

b) powołanie struktur wspomagających pozyskanie użytkowników i odbiorców do projektu,

c) pogłębione diagnozy problemu - polskie i zagraniczne,

d) opracowanie wstępnej wersji scouting $u$ wiedzy,

e) walidacja wstępna.

3. Faza realizacyjna:

a) testowanie - systematyczny rozwój koncepcji, dokonywanie niezbędnych zmian, uzupełnień,

b) ewaluacja zewnętrzna - trwająca przez okres testowania,

c) opracowanie finalnej wersji systemu scoutingu uwzględniającej doświadczenia $\mathrm{z}$ etapu testowania i uwagi ewaluatora,

d) walidacja finalna,

e) działania upowszechniająco-włączające.

Podstawą do podjęcia działań projektowych był problem niskiej współpracy uczelni wyższych z sektorem przedsiębiorstw. Praca w projekcie od chwili zainicjowania angażowała silnie użytkowników i odbiorców opracowywanego rozwiązania. Na etapie przygotowawczym, po ukonstytuowaniu się zespołu zarządzającego, powołano ciała wspomagające działania strategiczne oraz konsultacyjno-opiniodawcze. Były to:

1. Grupa sterująca, w skład której wchodzili:

a) przedstawiciel rektora,

b) przedstawiciel Wydziału Zarządzania,

c) przedstawiciel Wydziału Biologii i Ochrony Środowiska,

d) przedstawiciel Wydziału Chemii,

e) przedstawiciel Wydziału Fizyki i Informatyki Stosowanej,

f) przedstawiciel Wydziału Matematyki i Informatyki,

g) przedstawiciel Centrum Transferu Technologii,

h) przedstawiciel partnera,

i) kierownik projektu. 


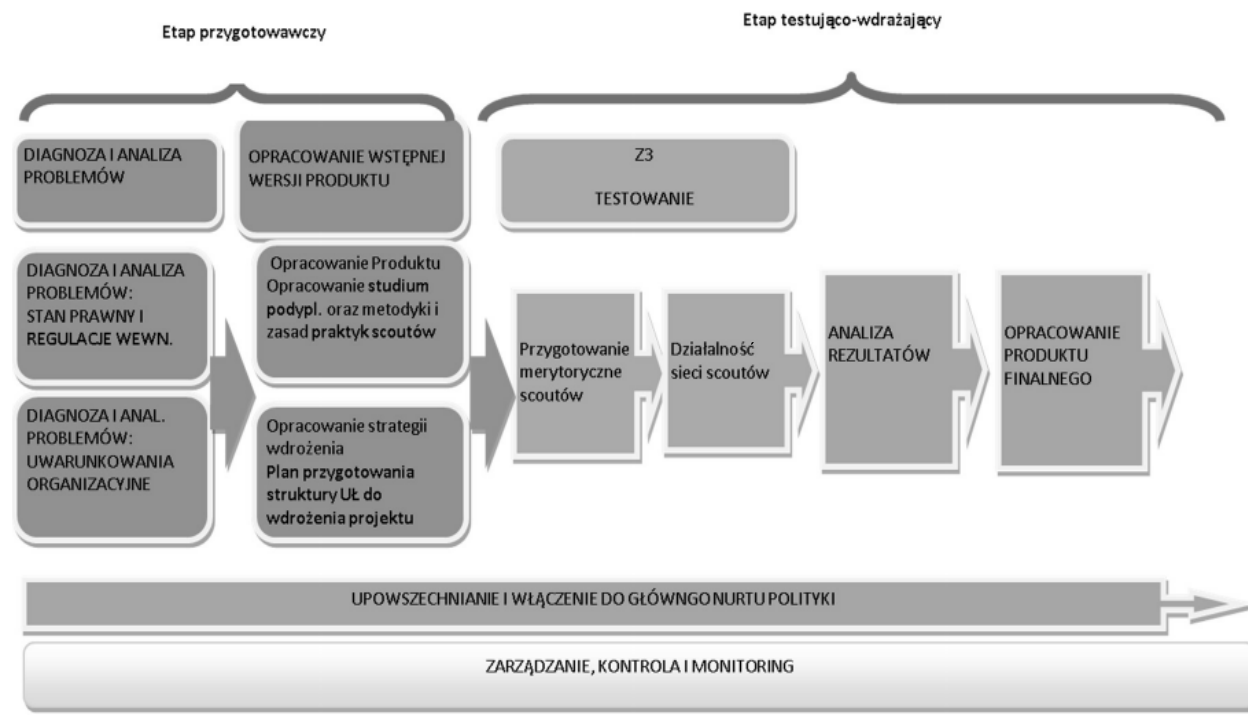

Rysunek 4. Struktura działań podejmowanych w projekcie „SCOUTING - aktywny system monitoringu i oceny potencjału rynkowego prac badawczych kluczem do współpracy nauki i przedsiębiorców"

Źródło: dokumentacja projektu „SCOUTING - aktywny system monitoringu i oceny potencjału rynkowego prac badawczych kluczem do współpracy nauki i przedsiębiorców".

2. Zespół konsultacyjno-opiniodawczy, w którego skład weszli eksperci z obszaru komercjalizacji wiedzy i transferu technologii, przedstawiciele władz Uniwersytetu Łódzkiego i uczelni regionu łódzkiego; przedstawiciel Centrum Transferu Technologii Uniwersytetu Łódzkiego i instytucji regionalnych związanych z komercjalizacją wiedzy i transferem technologii, przedsiębiorcy z regionu łódzkiego posiadający doświadczenie we współpracy z uczelnią lub jednostką B+R. 
Na etapie przygotowawczym przeprowadzono pogłębione analizy i doprecyzowano zidentyfikowany problem. Bariery powodujące niewielki stopień współpracy zidentyfikowano po obu stronach - przedsiębiorstw i uczelni ${ }^{13}$. Głównym celem projektu było zatem opracowanie rozwiązania na rzecz podniesienia zdolności uczelni w zakresie współpracy z przedsiębiorcami. Zdiagnozowane problemy stanowiły punkt wyjścia dla poszukiwania rozwiązań o charakterze systemowym, kompleksowym. Rozpoznane uwarunkowania tejże współpracy wskazały, iż rozwiązaniem może okazać się wypracowanie innowacyjnego systemu identyfikowania, monitorowania i oceny potencjału komercjalizacyjnego wyników prac badawczych, opartego na doświadczeniach partnerów ponadnarodowych. Takie rozwiązanie, zwane scoutingiem technologicznym czy scoutingiem wiedzy, stosowane jest w głównych uczelniach światowych.

„Scoutingiem technologicznym określa się systematyczne podejście przedsiębiorstwa, w ramach którego asygnuje ono część swoich zasobów ludzkich lub też zatrudnia konsultantów zewnętrznych w celu zbierania informacji z zakresu nauki i technologii, i które to podejście ułatwia pozyskiwanie technologii lub prowadzi do pozyskania technologii ${ }^{14}$ ".

W warunkach uczelni wyższej scoutingiem można określić pracę zespołu wyspecjalizowanych pracowników, których zadanie polega na systematycznym kontaktowaniu się z zespołami badawczymi w celu identyfikacji i oceny potencjału rynkowego prac badawczych z jednej strony oraz systematycznym śledzeniu potrzeb sektora przedsiębiorstw w obszarach, w których partnerem do współpracy mogliby być pracownicy naukowi uczelni wyższej, w której scouci są zatrudnieni.

${ }_{13}$ Zob. P. Niedzielski, K. Łobacz, Diagnoza i analiza problemów komercjalizacji wiedzy i transferu technologii na uczelni wyższej pod katem barier natury organizacyjnej, ekspertyza przygotowana w ramach projektu „SCOUTING - aktywny system monitoringu i oceny potencjału rynkowego prac badawczych kluczem do współpracy nauki i przedsiębiorców”, maszynopis powielony, Szczecin 2012; J. Długoński, Bariery w procesie komercjalizacji wiedzy w ramach uczelni wyższej, ze szczególnym uwzględnieniem biotechnologii, ekspertyza przygotowana w ramach projektu ,SCOUTING - aktywny system monitoringu i oceny potencjału rynkowego prac badawczych kluczem do współpracy nauki i przedsiębiorców”, maszynopis powielony, Łódź 2012; W. Olejniczak, Bariery w procesie komercjalizacji wiedzy w ramach uczelni wyższej, ze szczególnym uwzględnieniem nanotechnologii, ekspertyza przygotowana w ramach projektu „SCOUTING aktywny system monitoringu i oceny potencjału rynkowego prac badawczych kluczem do współpracy nauki i przedsiębiorców", maszynopis powielony, Łódź 2012.

14 R. Rohrbeck, Harnessing a Network of Experts for Competitive Advantage: Technology Scouting In the ICT Industry, „R\&D Management” 2010, Vol. 40, No. 2, za: M. Nowak, Scouting technologiczny, w: Innowacje i transfer technologii. Stownik pojęć, red. K.B. Matusiak, PARP, Warszawa 2010, s. 263, www.parp.gov.pl/index/more/25032 (dostęp 12.12.12). 
W ramach projektu powołano dwa zespoły. Ich zadaniem było opracowanie koncepcji scoutingu uczelnianego (rysunek 5). Założono wypracowanie dwóch filarów modelu: systemowego oraz edukacyjnego.

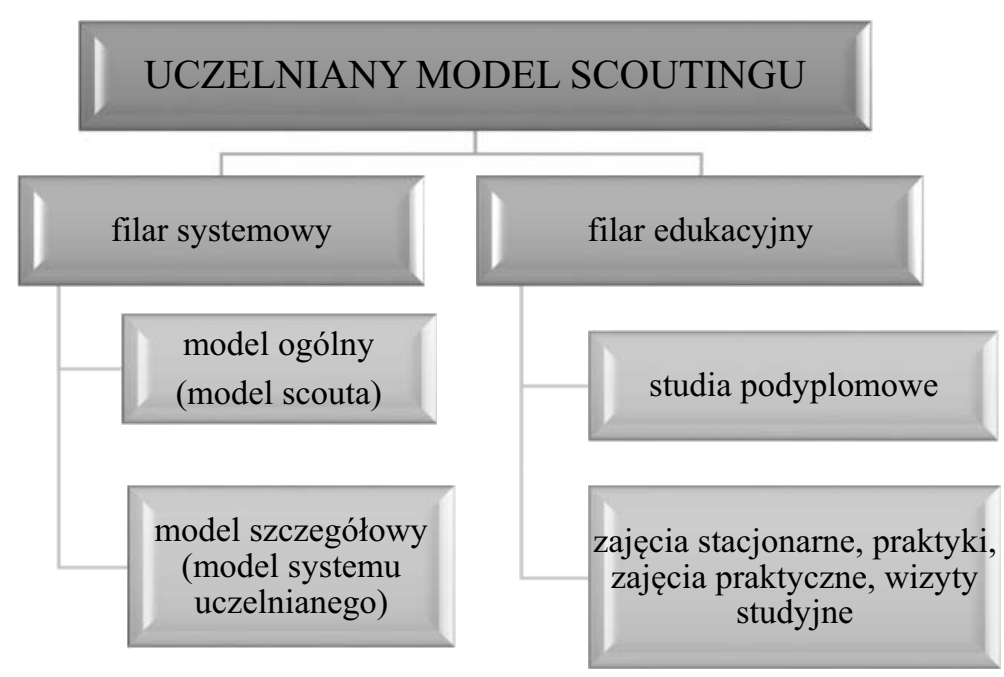

Rysunek 5. Uczelniany model Scoutingu - założenia projektu „SCOUTING - aktywny system monitoringu i oceny potencjału rynkowego prac badawczych kluczem do współpracy nauki i przedsiębiorców”

Źródło: opracowanie na podstawie: M. Wiśniewska, P. Głodek, M. Żak-Skwierczyńska, op. cit. s. $35-52$.

Filar systemowy ${ }^{15}$ oznaczał model tworzenia i działania sieci scoutów w ramach systemu komercjalizacji wiedzy i transferu technologii w uczelni wyższej. Składają się na niego dwa komponenty: tj. model ogólny oraz model szczegółowy.

Model ogólny, rozumiany jako model scouta, precyzuje profil scouta, jego predyspozycje, pełnioną funkcję, wykonywane zadania i oczekiwane kompetencje. Tak zdefiniowany scout odpowiedzialny jest za pozyskiwanie informacji na

15 Na podstawie materiałów projektu, w tym opracowania:: T. Czapla, T.B. Kalinowski, M. Malarski, M. Turała, Produkt Uczelniany model scoutingu wiedzy i technologii. Filar systemowy. Model tworzenia i działania zespolu scoutów w ramach systemu komercjalizacji wiedzy i transferu technologii na uczelni wyższej, dokument opracowany w ramach projektu ,SCOUTING - aktywny system monitoringu i oceny potencjału rynkowego prac badawczych kluczem do współpracy nauki i przedsiębiorców”, maszynopis powielony, Łódź 2012. 
temat prowadzonych prac naukowo-badawczych w uczelni, ocenę ich potencjału komercyjnego, poszukiwanie potencjalnych partnerów biznesowych i nawiązanie z nimi kontaktu oraz doprowadzenie do podjęcia współpracy między przedstawicielem uczelni a partnerem biznesowym.

Drugi komponent filaru systemowego to model szczegółowy, rozumiany jako model systemu uczelnianego. Na model ten składa się opis procesu scoutingu (mechanizmów związanych z pracą scouta) oraz zasad osadzenia scouta w strukturze uczelni. Obejmuje zatem ujęcie sieci scoutów w strukturze organizacyjnej uczelni, zasady zatrudniania, wynagradzania i kontrolowania, procedury postępowania i ochrony własności intelektualnej.

Drugim filarem uczelnianego modelu scoutingu wiedzy i technologii jest filar edukacyjny. Działania edukacyjne koncentrują się wokół merytorycznego i praktycznego przygotowania kandydatów na scoutów do pracy. Na ten filar składają się studia podyplomowe połączone z ponad półroczną pracą w roli scouta $\mathrm{w}$ ramach Uniwersytetu Łódzkiego. Oba filary opracowane zostały przez interesariuszy projektu, w tym głównie pracowników naukowych uczelni wyższych oraz specjalistów z zakresu komercjalizacji wiedzy i transferu technologii.

Wypracowane modele zostały poddane wstępnej walidacji, z wynikiem pozytywnym warunkowym. Po wprowadzeniu poprawek przystąpiono do testowania sieci. W pierwszej kolejności dokonano rekrutacji kandydatów na studia. Mogli nimi być przedstawiciele środowiska akademickiego, a więc przyszli odbiorcy rozwiązania. Po zakończeniu procesu edukacyjnego wybrani absolwenci studium przystąpili do pracy. Wyniki pracy sieci były bardzo pozytywne i z nawiązką spełniły założone do osiągnięcia efekty.

Tabela 1

Wybrane wskaźniki osiągnięte w ramach etapu testowania w podziale na wskaźniki produktu oraz wskaźniki rezultatu

\begin{tabular}{|l|c|c|}
\hline \multicolumn{1}{|c|}{ Wybrane wskaźniki } & Wskaźniki produktu & Wskaźniki rezultatu \\
\hline \multicolumn{1}{|c|}{1} & 2 & 3 \\
\hline $\begin{array}{l}\text { Liczba listów intencyjnych na UŁ podpisanych } \\
\text { z przedsiębiorstwami }\end{array}$ & - & 16 szt. \\
\hline $\begin{array}{l}\text { Liczba listów intencyjnych w tym } \\
\text { z przedsiębiorstwami i instytucjami spoza sektora } \\
\text { przedsiębiorstw }\end{array}$ & - & 24 szt. \\
\hline $\begin{array}{l}\text { Liczba pracowników naukowo-dydaktycznych } \\
\text { UŁ otrzymujących aktywne wsparcie w ramach } \\
\text { możliwości komercjalizacji wiedzy }\end{array}$ & - & 134 szt. \\
\hline
\end{tabular}




\begin{tabular}{|l|c|c|}
\hline \multicolumn{1}{|c|}{1} & 2 & 3 \\
\hline $\begin{array}{l}\text { Liczba ofert kadry naukowo-dydaktycznej UUŁ } \\
\text { otrzymujących aktywne wsparcie w ramach } \\
\text { możliwości komercjalizacji wiedzy }\end{array}$ & - & 22 szt. \\
\hline Liczba aktywnych scoutów & 10 osób & - \\
\hline
\end{tabular}

Źródło: dokumentacja projektu „SCOUTING - aktywny system monitoringu i oceny potencjału rynkowego prac badawczych kluczem do współpracy nauki i przedsiębiorców”.

Proces testowania podlegał systematycznemu monitorowaniu przez zespół zarządzający. Organizowano cykliczne spotkania sieci scoutów, które stanowiły podstawę do bieżących udoskonaleń opracowywanego rozwiązania. Istotną rolę odegrało upowszechnienie idei scoutingu wśród użytkowników i odbiorców rozwiązania. Pokonanie zdiagnozowanych barier wymagało działań mających na celu budowanie świadomości potrzeby współpracy uczeni i biznesu. Już na etapie testowania prace rozpoczął ewaluator zewnętrzny. Ewaluację tę prowadziła instytucja o dużym doświadczeniu w komercjalizacji wiedzy i transferze technologii. Ta opinia stanowiła podstawę do wdrożenia dodatkowych usprawnień do systemu. Po okresie testowania przystąpiono do kolejnej walidacji rozwiązania. Także i tym razem walidacja zakończyła się wynikiem pozytywnym warunkowym. Dokonane zmiany nie dotyczyły jednak istoty rozwiązania, a wyłącznie dokumentacji pozwalającej na sprawne wdrożenie rozwiązania. Opracowane rozwiązanie jest gotowe do wdrożenia przez dowolną uczelnię wyższą w Polsce. Wartością dodaną projektu okazało się stworzenie przyjaznych warunków dla komercjalizacji wiedzy z uczelni w różnych strukturach uczelnianych. Udało się to dzięki zaangażowaniu możliwie największej liczby przedstawicieli środowiska uczelnianego.

\section{Podsumowanie}

Living Lab jest niejako środowiskiem otwartej innowacji w warunkach codziennego życia, skoncentrowanym na wspólnym tworzeniu innowacji generowanej przez użytkowników i interesariuszy. Powstawanie nowości w takiej formule odbywać się może w wielu obszarach systemu społeczno-gospodarczego czy też codziennego życia człowieka. Z jej założeń korzystać może zarówno biznes, jak i instytucje publiczne czy organizacje pozarządowe. Jak już zostało to wspomniane, koncepcja Living Lab może z pewnością znaleźć swoje zastosowanie dla kreowania nowych rozwiązań w sektorze usług publicznych. Można też zastosować ją szerzej - na rzecz rozwoju społecznego czy gospodarczego. Dobrym przykładem będzie tworzenie narzędzi informatycznych dla społeczeństwa 
informacyjnego, w tym budowa e-administracji. Wzmacnianie relacji nauka-biznes, przedsięwzięcia prośrodowiskowe to ważne obszary zastosowań tego podejścia. Warto także rozważyć to podejście przy zagospodarowywaniu przestrzeni publicznych.

\section{Literatura}

Ballon, P., Pierson, J., Delaere, S., Test and Experimentation Platforms for Broadband Innovation: Examining European Practice, w: Conference Proceedings of 16th European Regional Conference by the International Telecommunications Society (ITS), Porto, Portugal, 4-6 September, 2005.

Bergvall-Kareborn B., Stahlbrost A., Living Lab-An Open and Citizen-Centric Approach for Innovation, „International Journal of Innovation and Regional Development” 2009, Vol. 1 (4),

Bielski M., Podstawy teorii organizacji i zarzadzania, wyd. 2 rozsz., C.H. Beck, Warszawa 2004.

CoreLabs., Living Labs Roadmap 2007-2010, Recommendations on Networked Systems for Open User-Driven Research, Development and Innovation, http://pl.scribd. com/doc/38953413/Living-Labs-Roadmap-2007-2010\#scribd (19.09.2015).

Cyfert Sz., Krzakiewicz K., Teoria stakeholders. Krytyka założeń. Stan i perspektywy rozwoju teorii i praktyki zarzadzania na progu XXI wieku, Prace Naukowe Akademii Ekonomicznej we Wrocławiu nr 940, 2002.

Czapla T., Kalinowski T.B., Malarski M., Turała M., Produkt Uczelniany model scoutingu wiedzy i technologii. Filar systemowy. Model tworzenia i działania zespołu scoutów w ramach systemu komercjalizacji wiedzy i transferu technologii na uczel$n i$ wyższej, dokument opracowany w ramach projektu „SCOUTING - aktywny system monitoringu i oceny potencjału rynkowego prac badawczych kluczem do współpracy nauki i przedsiębiorców”, maszynopis powielony, Łódź 2012.

Długoński J., Bariery $w$ procesie komercjalizacji wiedzy w ramach uczelni wyższej, ze szczególnym uwzględnieniem biotechnologii, ekspertyza przygotowana $\mathrm{w}$ ramach projektu „SCOUTING - aktywny system monitoringu i oceny potencjału rynkowego prac badawczych kluczem do współpracy nauki i przedsiębiorców”, maszynopis powielony, Łódź 2012.

Eriksson M., Hribernik K.A., State-of-the-art and Good Practice in the Field of Living Labs. w: Proceedings of the 12th International Conference on Concurrent Enterprising: Innovative Products and Services through Collaborative Networks, Milan, Italy 2006.

Lama N., Oigin A., Innovation ECOSYSTEMS: Services Engineering \& Living Labs a Dream to Drive Innovation?, Presentation at the EU/IST conference, Helsinki 2006.

Niedzielski P., Łobacz K., Diagnoza i analiza problemów komercjalizacji wiedzy i transferu technologii na uczelni wyższej pod katem barier natury organizacyj$n e j$, ekspertyza przygotowana w ramach projektu „SCOUTING - aktywny system 
monitoringu i oceny potencjału rynkowego prac badawczych kluczem do współpracy nauki i przedsiębiorców”, maszynopis powielony, Szczecin 2012.

Nowak M., Scouting technologiczny, w:, Innowacje I transfer technologii. Stownik pojęć, red. K.B. Matusiak, PARP, Warszawa 2010, s. 263, www.parp.gov.pl/index/ more/25032 (dostęp 12.12.12).

Olejniczak W., Bariery $w$ procesie komercjalizacji wiedzy $w$ ramach uczelni wyższej, ze szczególnym uwzględnieniem nanotechnologii, ekspertyza przygotowana w ramach projektu „SCOUTING - aktywny system monitoringu i oceny potencjału rynkowego prac badawczych kluczem do współpracy nauki i przedsiębiorców”, maszynopis powielony, Łódź 2012.

Rohrbeck R., Harnessing a Network of Experts for Competitive Advantage: Technology Scouting In the ICT Industry, ,R\&D Management” 2010, Vol. 40, No 2.

Schaffers H., Cordoba M. C., Hongisto P., Kallai T., Merz C., Van Rensburg J., Exploring Busniess Models for Open Innovation in Rural Living Labs, in: Proceedings of the 13th International Conference on Concurrent Enterprising, Sophia-Antipolis 2007.

Stawasz D., Wiśniewska M., Wykorzystanie koncepcji Living Lab w zarządzaniu jednostkami samorządu terytorialnego, Wydawnictwo Katedry Zarządzania Miastem i Regionem, Wydział Zarządzania Uniwersytetu Łódzkiego, Łódź 2015.

Wiśniewska M., Głodek P., Żak-Skwierczyńska M., Scouting - system identyfikacji $i$ monitoringu wiedzy $w$ uczelni wyższej jako instrument na rzecz wzmocnienia powiazań nauki i biznesu, Folia Oeconomica z. 277, Wydawnictwo Uniwersytetu Łódzkiego, Łódź 2012.

\section{THE IMPLEMENTATION OF LIVING LAB IN UNIVERSITIES - KNOWLEDGE SCOUTINGU AT UNIVERSITY OF LÓDŹ}

\section{Summary}

The concept of Living Lab is a relatively new approach to the creation and implementation of innovative solutions in organizations. Its basic assumption is the end-user participation in the entire process of creating new products. At the basis of this concept is the belief that the effectiveness of new solutions will be higher when those end users will create a novelty in circumstances of its actual application. Article introduces the concept of Living Lab and presents practical possibilities of its application. Theoretical considerations have been supported by case study of knowledge scouting - solution prepared and tested in the University of Lodz.

Keywords: Innovation, Living Lab, scouting 
